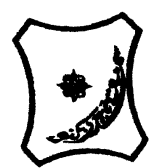

Bayero Journal of Pure and Applied Sciences, 11(1): 131 - 137

Received: January, 2018

Accepted: May, 2018

ISSN $2006-6996$

\title{
EFFECT OF ORGANIC FERTILIZER ON NUTRITIONAL STATUS OF HibisCus sabdariffa AT A VEGETATIVE STAGE OF GROWTH
}

${ }^{1}$ Getso, M. M., ${ }^{2}$ Sallau, M. S., ${ }^{2}$ Abechi, S.E and ${ }^{2}$ Uba, S.

1. Animal Science Department, KUST, Wudil, Kano, Nigeria

2. Department of Chemistry, Ahmadu Bello University, Zaria, Nigeria

Corresponding author: muhammadmusagetso@gmail.com

\section{ABSTRACT}

Field experiment was conducted at Research Farm of Kano University of Science and Technology, Wudil, to determine the effects of organic fertilizer on the nutritional status of Hibiscus sabdariffa (Roselle). The results obtained indicated the manure fertilizer to be higher in protein (20.910\%) and crude fiber contents (12.047\%), Zn (30.689mg/kg) and Cu (18.571 $\mathrm{mg} / \mathrm{kg})$ concentrations, no Pb was detected at all. However, the difference that exists amongst the fertilizers (T2 and T3) and poultry manure (T1) was found to be insignificant in so many parameters. Therefore, the study work with regard to the findings revealed that organic fertilizer (poultry manure) had the potential over the inorganic fertilizers for the dietary nutrients yielding in vegetables Hibiscus sabdariffa. However, the information will economically favor our local farmers and users to adapt the cheapest poultry manure for the optimum yield of qualitative produce vegetable as prospective against malnutrition in Nigeria especially North East where endemically affected by war.

Key words; Roselle leaves, vegetative stage, proximate analysis, elements, Kano

\section{INTRODUCTION}

Multitude factors can lead to malnutrition. These include poverty which prevents accessibility to nutritious food and basic farm inputs and also non reliable source in supplying food throughout the year. With an increase in the cost of mineral fertilizer and their future availability, there is renewed interest in organic recycling to improve soil fertility and productivity (Parr and Hornick, 1990). Evidence has shown that, indigenous vegetables offer a significant opportunity for the poorest people to earn a living as producers without requiring large capital investments (Schippers, 2000). Ali and Abdel-Mouty (2000) reported that, applying significant amount of organic matter becomes necessary in improving soil physical and chemical conditions. Vegetables are widely grown in the North- Eastern and middle belt regions of Nigeria (Akanya et al., 1997).Vegetables nutritive value depends in part on the soil and climate in which they are grown. Roselle has been found to thrive on a wide range of soil conditions. It can perform satisfactorily on relatively infertile soils but for economic purposes, a soil well supplied with organic materials and essential nutrients is essential (Tindal, 1986).

The World Health Organization had issued reports claiming that correct fresh vegetables produce intake alone could save 2.7 million lives a year and that $31 \%$ of heart disease cases are due to an insufficient intake of such foods (Johnston et al., 2006). Indigenous leafy vegetables such as Hibiscus sabdariffa (roselle), kenaf, spinach and amaranth, serve as indispensible constituents of the human diet (Ogunlesi et al., 2010).

This work was carried out to exploit the feasibility of using organic fertilization as a substitute to mineral fertilizer for growing the dietary crops. There is an increasing demand for the organically produced vegetables, for their health and nutritional values. However, there is scanty information to encourage the usage of an environmentally friendly and economically cheap fertilizer against mineral fertilizers that are always on hike in the market. The plant Hibiscus sabdariffa studied for its proficiency to sustain organic farming diversification on our available indigenous plant was the objective of this work, to evaluate and give confidence to our farmers in organic fertilizer usage over the conventional inorganic and expensive types.

Aim of the Work

The aim of this work was to assess the nutritional status of Hibiscus sabdariffa at a vegetative stage.

\section{Objectives}

The aim of the research was achieved through the following set objectives;

i. To investigate the proximate constituents, essentials, and minerals concentrations of the Hibiscus sabdariffa at a dietary vegetative.

ii. To determine the level of anti-nutrient contents (oxalates and tannins) in the dietary leaves sample at this stage of growth.

iii. To compare the levels of the analytes in the samples between organic and mineral fertilizers using student's t-test for analysis of variance to test whether there is significance difference in the levels of the nutrients.

\section{MATERIALS AND METHODS}

Description of the study area

The study was conducted at Kano University of Science and Technology, Wudil Research Farm Kano State, in Northern-Western Nigeria. The geographical coordinates of this farm is; latitude $11^{\circ} 51^{\prime} 28.05^{\prime \prime} \mathrm{N}$, longitude $8^{0} 59^{\prime} 11.76^{\prime \prime} \mathrm{E}$, and on altitude of $430 \mathrm{~m}$ above sea level. 
The area has mean annual rain fall of about $800 \mathrm{~mm}$ with relative humidity of $75 \%$ during the rainy season and the annual temperature $\left(25^{\circ} \mathrm{C}-26^{\circ} \mathrm{C}\right)$.

\section{Experimental design}

The experimental design, consisted of a complete randomized block design with three replications, the distance between two consecutive blocks was $1 \mathrm{~m}$ and $2 \mathrm{~m}$ between replicates. The block was $3.6 \mathrm{~m}$ long and $4.9 \mathrm{~m}$ wide. All plots consisted of 6 rows of plants with $0.7 \mathrm{~m}$ apart and $0.6 \mathrm{~m}$ intra spacing within rows in the farm land. The work was carried out between July to November, 2014 during the rainy season.

\section{Crop establishment and Treatments}

The black variety of Hibiscus sabdariffa plant was used for this research and identified at Crop Science Department KUST, Wudil. The organic manure was also applied uniformly after land preparation before sowing at a rate of $10 \mathrm{ton} / \mathrm{ha}$ (T1), and the other treatments were from mineral fertilizer NPK $15-15-15$ at the rate of $75 \mathrm{~kg} \mathrm{~N} / \mathrm{ha}$ (T2) and $100 \mathrm{~kg} \mathrm{~N} / \mathrm{ha}$ (T3) respectively. The seeds were directly sown by digging in furrows after rainfall. The thinning was done to an intra-row spacing three weeks after planting. Shallow cultivation was observed using hoe and hand pulling to keep the plants weed free, for about three times (Grubben, 2004).

\section{Sample collection}

Four central rows of Hibiscus sabdariffa L. (Roselle) were sampled at 25 days after sowing (vegetative stage) from the farmland plot. The collected samples were thoroughly separated into organs, rinsed with de-ionized water and the residue evaporated at room temperature on a clean background paper with constant turning over to prevent fungal growth. The dried sample was however, grounded into a fine powder using pestle and mortar, and packed in an air tight plastic container for the analyses.

Lists of apparatus/equipment used

i. Instruments; Atomic Absorption Spectrophotometer, Flame Emission Spectrophotometer, Centrifuge, Water bath, Hot air oven, Soxhlet extractor, Fiber cap, Heating mantle, Hot plates, Digestion block, Muffle furnace, Analytical balance, Refluxing component.

ii. Glass wares; Volumetric flasks, Conical flasks, Measuring cylinders, Filter papers (No.1 and No. 44), Crucibles, Petri dishes, Distillation flasks, Pipette, Burettes.

\section{Chemical and reagents}

All the chemicals and reagents used in this study were of analytical grade and are the products of Sigma Aldrich.

\section{List of reagents used}

Perchloric acid (60\%).

Conc. Nitric acid.

Conc. Sulphuric acid.

Catalyst; $500 \mathrm{~g} \mathrm{Na}_{2} \mathrm{SO}_{4}, 50 \mathrm{~g}$ anhydrous copper

sulphate, $0.5 \mathrm{~g}$ of selenium powder mixed

and ground to powder.
Boric acid (2\%).

$\mathrm{NaOH}(40 \%)$

$0.01 \mathrm{M} \mathrm{HCl}$

$\mathrm{NaCO}_{3}(17 \%)$

Petroleum ether $\left(40-60^{\circ} \mathrm{C}\right.$ boiling point).

$\mathrm{KMnO}_{4}$

$\mathrm{NH}_{4} \mathrm{OH}$

i. Tannic acid standard; $0.05 \mathrm{~g}$ tannic acid was dissolved in water and diluted to $500 \mathrm{~cm}^{3}$ (1 $\mathrm{cm}^{3}=0.1 \mathrm{mg}$ tannic acid of the stock solution). This was prepared fresh.

ii. Folin-denis reagent; $50 \mathrm{~g}$ of sodium tungstate was added to $375 \mathrm{~cm}^{3}$ of water, followed by $10 \mathrm{~g}$ phosphomolbdic acid and then $25 \mathrm{~cm}^{3}$ orthophosphoric acid added and mixed together. This was also prepared a fresh.

iii. Mix indicator; $0.2 \mathrm{~g}$ of methyl blue weighed into $100 \mathrm{~cm}^{3}$ flask, also $0.4 \mathrm{~g}$ methyl red added into another $100 \mathrm{~cm}^{3}$ flask. Both were dissolved using ethanol and mixed in $200 \mathrm{~cm}^{3}$ volumetric flask thoroughly.

iv. Calibration curve

The calibration curves prepared for each element were by serial dilution out of the stock solution. The standard and blank solutions were aspirated first in the instruments (Atomic Absorption and Flame Emission Spectrophotometers) for standardization, blanking and the establishment of calibration curves at a required wave length as; $283.3 \mathrm{~nm} \mathrm{~Pb}$, 279.5nm Mn, 3248nm Cu, 248.3nm Fe and $213.8 \mathrm{~nm}$ for the $\mathrm{Zn}$ respectively (Allen et al., 1974).

\section{Proximate Analysis}

The recommended methods of the Association of Official Analytical chemists (AOAC, $1995 ; 2010)$ were used in the determination of moisture, ash, crude fat, fiber, and protein and carbohydrate contents.

\section{(a) Determination of moisture content}

Moisture content was determined according to the standard method described by AOAC (1995). About $5 \mathrm{~g}$ of fresh sample was weighed and placed in a clean dry moisture dish and the weight of the sample and dish taken. These were placed in a free heated hot air oven at the temperature of $105^{\circ} \mathrm{C}$. The samples were dried for 3 hours, cooled in desiccators and weighed. The method was repeated at I hour interval until a constant weight was obtained. The moisture content in the samples were calculated using the formula:

$\%$

Weight of sample before drying-weight of sample after drying $\times 100$

\section{(b) Determination of ash content}

$5 \mathrm{~g}$ of a fresh sample was weighed into a cleaned weighed crucible, and charred by heating in a fumes hood till smoking ceased. 
Bajopas Volume 11 Number 1 June, 2018

The charred samples were then transferred to a muffle furnace and the temperature was increased gradually to $550^{\circ} \mathrm{C}$. The samples were then turned completely ash. Temperature was reduced, samples were removed and cooled in a desiccators before weighing (AOAC, 1995). The amount of ash was therefore calculated using the formula:

$$
\% \text { Ash }
$$

$\frac{\text { Weight of crucible+ash-weight of empty crucible }}{\text { Weight }} \times 100$

$$
\text { Weight of sample }
$$

\section{(c) Determination of protein content}

One gramme $(1 \mathrm{~g})$ of sample was weighed into a digestion flask together with a combined catalyst of 5 $\mathrm{g}$ potassium sulphate and $0.5 \mathrm{~g}$ of copper sulphate and $15 \mathrm{ml}$ of sulphuric acid. The mixture was heated in a fume hood till the digest color turned blue. The digest was cooled, transferred to $100 \mathrm{ml}$ volumetric flask and topped up to the mark with de-ionized water. A blank digestion with the catalyst was also made. Exactly $10 \mathrm{ml}$ of the diluted digest was transferred into the distilling flask and washed with distilled water. $15 \mathrm{ml}$ of $40 \% \mathrm{NaOH}$ was added and this was also washed with distilled water. Distillation was done to a volume of about $60 \mathrm{ml}$ distillate. The distillate was then titrated using $0.02 \mathrm{M} \mathrm{HCl}$ to an orange color of the mixed indicator, which signified the end point (AOAC, 1995). The nitrogen in the samples was calculated using the formular below;

$$
\% \text { Nitrogen }=\frac{(\mathrm{V} 1-\mathrm{V} 2) \times \mathrm{N} \times \mathrm{F}}{(\mathrm{VXS})} \times 100
$$

Where:

$\mathrm{V}_{1}=$ the titre for sample in $\mathrm{ml}, \mathrm{V}_{2}=$ titre for blank in $\mathrm{ml}, \mathrm{N}=$ normality of standard $\mathrm{HCl}(0.02), \mathrm{F}=$ factor of std $\mathrm{HCl}$ solution, $\mathrm{V}=$ volume of diluted digest taken for distillation $(10 \mathrm{ml})$,

$\mathrm{S}=$ weight of sample taken for distillation $(1 \mathrm{~g})$.

The protein content was then calculated as:

$\%$ protein $=$ Nitrogen $\mathrm{x}$ protein factor $(6.25)$.

\section{(d) Determination of fat content}

A $250 \mathrm{ml}$ boiling flask was washed, dried in an oven (at $105-110^{\circ} \mathrm{C}$ ) and then cooled in a desiccator. About $2 \mathrm{~g}$ of the sample $\left(\mathrm{W}_{2}\right)$ was weighed using an electronic balance and put in the extraction thimble and then plugged. It was then placed back in the soxhlet apparatus. The cleaned boiling flask was also filled to about $2 / 3(\mathrm{ml})$ with petroleum ether of $40-60^{\circ} \mathrm{C}$ boiling point range. The Soxhlet apparatus was then assembled and allowed to flux for about 6 hours which then completed the extraction. The thimble was carefully removed and dried at $80^{\circ} \mathrm{C}$ for 30 minutes in the oven and cooled in a desiccator and then finally weighed $\left(W_{3}\right)(A O A C, 2010)$. The fat content was calculated as follows;

$$
\% \text { fat content: }=\frac{\mathrm{W} 2-\mathrm{W} 3}{\mathrm{~W} 1} \times 100
$$

Where: $W_{1}=$ Weight of empty thimble, $W_{2}=$ Weight of empty thimble + sample, $W_{3}=$ Weight of $W_{2}$ after extraction.

\section{(e) Determination of crude fiber content}

About $2 \mathrm{~g}\left(\mathrm{~W}_{1}\right)$ of sample was weighed using analytical balance and put in a $250 \mathrm{ml}$ beaker, then boiled for 30 minutes with $100 \mathrm{ml}$ of $0.12 \mathrm{M} \mathrm{H}_{2} \mathrm{SO}_{4}$ and filtered through a funnel. The filtrate was washed with boiling water until the washing was no longer acidic. The solution was then boiled for another 30 minutes with $100 \mathrm{ml}$ of $0.012 \mathrm{M} \mathrm{NaOH}$ solution, filtered with hot water and methylated spirit three times. The residue was then transferred into a crucible and dried in the oven for 1 hour. The crucible with its content was then cooled in a desiccator and then weighed $\left(W_{2}\right)$. The residue was then taken into a furnace for ash at $600^{\circ} \mathrm{C}$ for 1 hour. The ashes sample was then removed from the furnace and put into the desiccator for cooling and later weighed $\left(\mathrm{W}_{3}\right)$ using balance (AOAC, 2010).

The percentage crude fiber was calculated thus:

$\%$ Crude fiber content $=\frac{\mathrm{w} 2-\mathrm{W} 3}{\mathrm{~W} 1} \times 100$

\section{(f) Determination of carbohydrate content}

The carbohydrate content was determined by difference in proximate analysis as described by Oyenuga (1968) using the equation below;

$\%$ Carbohydrate $=[100-(\%$ Moisture $+\% A s h+$

$\%$ Protein $+\%$ fat $+\%$ fiber $)]$ (AOAC, 2010)

\section{Estimation of energy value}

The sample calorific value was therefore estimated (in Kcal), by multiplying the percentage crude protein, crude lipid and carbohydrate with the recommended factor (2.44, 8.37 and 3.57 respectively used) in proximate analysis (Asibey-Berko and Tayie, 1999).

\section{Determination of Tannin contents}

The sample of approximately $0.1 \mathrm{gram}$ was weighed into $100 \mathrm{~cm}^{3}$ conical flask, $50 \mathrm{ml}$ of water then added, mixed and boiled for 1 hour using hot plate. The extract was then filtered whilst warm through No.44 filter paper into a $50 \mathrm{~cm}^{3}$ volumetric flask. The filtered diluted to volume after cooling by running the water onto the extract residue on filter paper, blank also received the same treatment. The color was developed by pipetting a suitable aliquot ( 5 $\mathrm{cm}^{3}$ ) of the sample, where then 0 to $3 \mathrm{~cm}^{3}$ of tannic acid pipetted into $50 \mathrm{~cm}^{3}$ volumetric flask making range of ( 0 to $0.3 \mathrm{mg}$ ) tannic acid standard, at this point, the samples and standard solutions were then treated equally by adding water to each flask up to two-third full. The folin-denis reagent solution $2.5 \mathrm{~cm}^{3}$ was added followed by $10 \mathrm{~cm}^{3}$ of $\mathrm{Na}_{2} \mathrm{CO}_{3}$ solution mixed and diluted to mark. The mixture finally kept in water bath at $25^{\circ} \mathrm{c}$ temperature for 20 minutes, where the optical density of standard read and obtained calibration curve of mg tannic acid for the samples at $760 \mathrm{~nm}$. Blank reading was also measured for subtraction from the sample.

Calculation for tannin content;

Soluble tannin $(\%)=\frac{\mathrm{C}(\mathrm{mg}) \mathrm{x} \text { extract volume }(\mathrm{cm} 3)}{10 \text { xaliquot }(\mathrm{ml}) \times \text { sample wt }(\mathrm{g})}$

\section{Determination of oxalate content}

According to the AOAC (1999) method, oxalate was determined by weighing $0.1 \mathrm{~g}$ of sample and mixed with $30 \mathrm{~cm}^{3}$ of $1 \mathrm{M} \mathrm{HCl}$. Each mixture was then shaken in a water bath at $100^{\circ} \mathrm{C}$ for 30 minutes. 
Bajopas Volume 11 Number 1 June, 2018

To each extract, $0.5 \mathrm{ml}$ of $5 \%$ calcium chloride was added and mixed thoroughly for the precipitation of calcium oxalate. The suspension was then centrifuged at $3000 \mathrm{rpm}$ for 15 minutes to separate the supernatant. The pallets were washed twice with $2 \mathrm{~cm}^{3}$ of $0.35 \mathrm{M} \mathrm{NH} \mathrm{N}_{4} \mathrm{OH}$ and dissolved into a $0.5 \mathrm{M} \mathrm{H}_{2} \mathrm{SO}_{4}$. The mixture was then titrated with $0.1 \mathrm{M}$ $\mathrm{KMnO}_{4}$ solution while, temperature maintained at $60^{\circ} \mathrm{C}$. Where the end point was achieved as the faint violet color appeared and persisted for at least 15 seconds. The oxalate contented calculated as; $1 \mathrm{~cm}^{3}$ titer value was equivalent to $2.2 \mathrm{mg}$ of oxalate.

\section{Mineral Analysis}

The minerals comprising the elements; Manganese, Iron, Zinc, Lead and Copper, which were determined according to the method of Allen et al., (1974), by Atomic absorption spectrometer, where their absorption compared with that of standards for the respective elements.

Digestion of plant sample for elemental analysis
$0.20-0.50 \mathrm{~g}$ of oven dried plant sample was weighed into a $100 \mathrm{ml}$ khjeldahl flask. $1 \mathrm{ml} 60 \% \mathrm{HClO}_{4}$, $5 \mathrm{ml} \mathrm{HNO}_{3}$ and $0.5 \mathrm{ml} \mathrm{H}_{2} \mathrm{SO}_{4}$ was added, swirled gently and digested slowly at a moderate heat and increased later for 15 minutes after white fumes appeared and cooled. The digests were then diluted and filtered using No.44 paper, into $50 \mathrm{ml}$ volumetric flask and diluted to mark. Also, blank was treated the same way and then used for blanking before the elemental analysis by Atomic Absorption Spectrometry (Allen et al., 1974).

\section{Data analysis}

All determinations were carried out in triplicates. The data generated from the experiments were subjected to statistical analysis using the Statistical Package for Social Science (SPSS) Version 16. Descriptive statistics, ANOVA and post hoc (LSD) were used to interpret the results obtained.

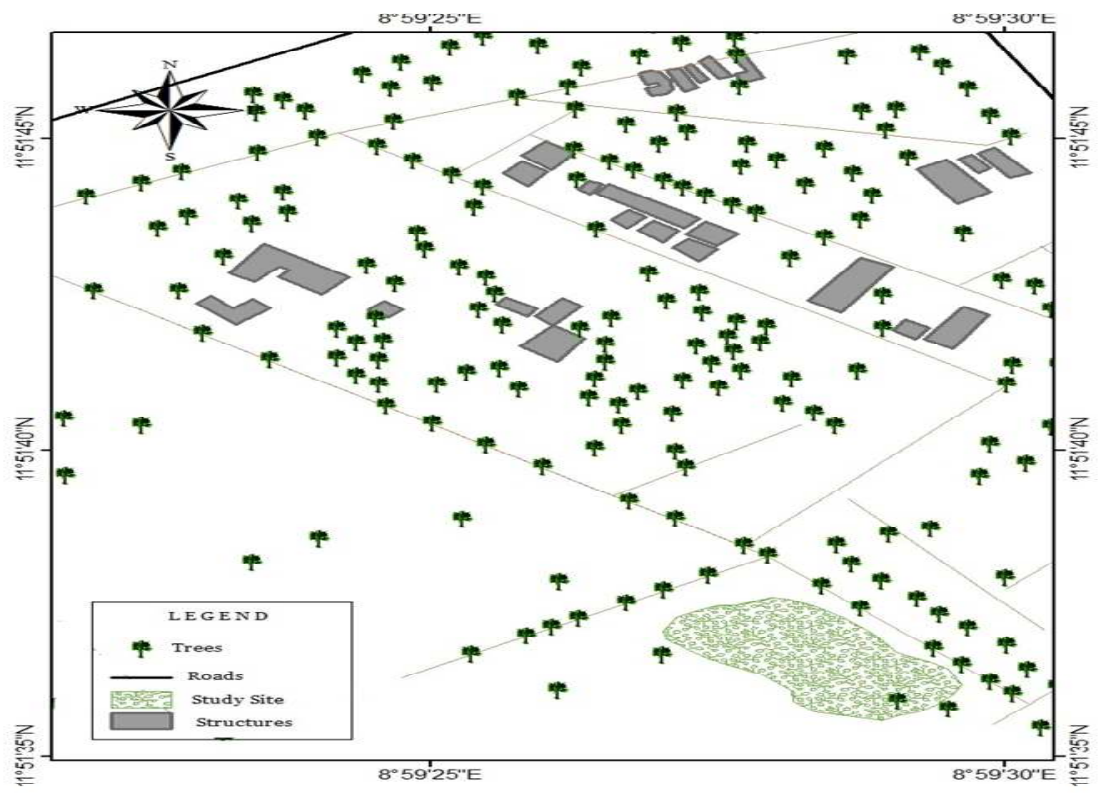

Figure 3.1 : Map of KUST Research Farm, Gaya ind ic ating the sampling site

SOURCE: GIS Unit, Dept. of Geography KUST, Wudil (2017)

\section{RESULTS AND DISCUSSION}

Analysis of proximate and mineral compositions has shown the ability of organic fertilizer in nutrients supplementation as presented in Tables 1 and 2, when compared to mineral fertilizers, where the anti-nutrients contents from Table 3, does not implicate any toxicity to the dietary vegetable produced(Hibiscus sabdariffa).

\section{Proximate composition}

The poultry manure $(M)$ had the highest protein $(20.910 \%)$ and crude fiber(12.047\%) contents compared to mineral fertilizers studied, this was in line with the findings of Dania et al., (2014) who worked on moringa and compared the NPK fertilizer with organo-mineral fertilizer. However, the result was comparably similar to that of Ren et al., (2014) who demonstrated that soil organic carbon and total nitrogen pool concentrations in the $0-10 \mathrm{~cm}$ soil layer decreased significantly without organic manure and mineral $\mathrm{N}$ applications, primarily because of the decomposition of stable carbon.

However, when observing at the mineral fertilizers' influence; the fertilizer concentration at a rate of $100 \mathrm{~kg}$ per hectare (F100) had shown predominantly higher contents in ash, crude fat and carbohydrate, but only found significant with crude fat content alone. In addition, the moisture content that recorded exceptionally higher was found with mineral fertilizer at $75 \mathrm{~kg}$ per hectare (F75) Table 1.

This is also analogous to the findings of (Akanbi et al., 2010), who investigated that the application of $75 \mathrm{~kg}$ $\mathrm{N} / \mathrm{ha}$, gave the highest okra fruit yield, and is a good determinant for the marketable produce vegetables like okra and Hibiscus sabdariffa for their demand is always coupled to their freshness, even though to our findings here the difference exist was found statistically insignificant in comparison to organic manure fertilizer. 
The results of the statistical analysis from all the proximate compositions revealed that the difference that existed among the fertilizers studied was found insignificant, which means poultry manure fertilizer ( $M$ ) has the equivalent power to other minerals fertilizers except, in the crude fat content where F100 fertilizer became significant at $(p>0.05)$ compared to other fertilizers investigated. This clearly revealed that the concentration of mineral fertilizer F100 increased the dry matter content of Hibiscus sabdariffa, that proportionally enhanced the crude fat content remarkably by the higher fertilizer level used. This is in harmony to the findings of Akanbi et al.(2010), who reported that, the dry matter yield increases with an increased in compost rate peak at $6.0 \mathrm{mg} /$ ha for most $\mathrm{N}$ levels in okra. The information will require future research for Hibiscus sabdariffa to be included in a campaign for the renewable energy sources from vegetable oils production that has increased rapidly in recent years (Onder Ustundag et al., 2013).

\section{Mineral composition}

The highest concentrations of mineral $\mathrm{Zn}$ and $\mathrm{Cu}$ were recorded from $M$ fertilizer (Table 3). However, the results were found similar to the work of Michael et al, (2010), who studied the effect of fertilizers on red lettuce as the chicken manure exhibited relatively higher values on number of leaves, plant height, marketable yield and mean leaf dry mass. Also Akanbi et al, (2010) reported the same influence on growth, dry matter and fruit yields components of okra. Moreover, the maximum $\mathrm{Zn}$ and $\mathrm{Cu}$ concentrations recorded in $\mathrm{M}$ fertilizer indicated that, manure is a good fertilizer for the supplementation of these elements better, which is found in harmony to the work of Kadiri et al., (2015). The greater levels of zinc recorded from this study are adequate when compared to recommended dietary allowance (RDA) value of $15 \mathrm{mg} /$ day for men and $12 \mathrm{mg} /$ day, for women and, the consumption of this plant will correct zinc deficiency in developing countries. In addition, the copper concentration was found to be above the RDA value of $12 \mathrm{mg} /$ day (Dickson, et al., 2012) except, for the F75 fertilizer, although the values recorded were still within the permissible limit of $20 \mathrm{mg} / \mathrm{kg}$ (WHO/FAO, 2001).Vegetables are dependable for their minerals, vitamins, fibers and other nutrients which are essential for metabolism, tissue formation and reproduction. Henceforth, the poultry manure deserved to be a substituent fertilizer over the mineral fertilizers for its potential and economic advantage.

On the other hand the mineral fertilizers; F100 fertilizer reported with higher $\mathrm{Mn}$ and Fe concentrations, and yet the difference was statistically found insignificant among the fertilizers. Nonetheless, the element $\mathrm{Fe}$ concentrations obtained can be adequately considered when compared to RDA value of $8 \mathrm{mg}$ Fe/day for men (19 years and older) and for women over 50 years, $18 \mathrm{mg} /$ day for (girl and women) 11 to 56years (FNB, 2001). The Food and Nutrition Board (NRC, 1980) recommends $10 \mathrm{mg}$ of iron per day for children between 1 to 10years. Minerals components like, iron concentrations of foods is the most important constituent of forming hemoglobin, which is the bare root of anaemia, and this will validated the use of Hibiscus sabdariffa as a vegetable plant to be recommended as good and cheap source for dietary Fe. The difference that exist amidst the fertilizers (Table 3), was found to be insignificant at $(p>0.05)$, which proven the fairness of fertilizers effect toward the growing and nutritional yield in Hibiscus sabdariffa.

Importantly, the $\mathrm{Pb}$ concentration recorded were at below detection level amidst the fertilizers used for this study, and its absence at the harvesting stage is exhibiting evidence that, Hibiscus sabdariffa vegetable is safe for patronage as dietary vegetable diet. Similarly, the harvesting time piloted for this study is the most frequent period for the plant usage in many traditional dishes like stew, soup, meal and tea. In this regard, our finding is in agreement to the statement of Mohammed and Sharif, (2011), who indicated that vegetables are valuable sources of nutrients most especially in local communities consisted of predominantly poor people. Besides, the research findings revealed that, green leafy vegetables are indispensible food crops that provide safe mineral nutrients, depending on the vegetable consumed (Fasuyi, 2006). This clearly revealed that poultry manure is capable of minerals nutrients supplementation.

\section{Anti-nutrients composition}

These are very important parameters in the dietary plant harvest and fertilization. Oxalate contents were observed to decreased with an increase of mineral fertilizer level in the soil and ranged from $8.190-9.978 \%$ (Table 2), in which $M$ fertilizer had the highest content and F100 was the least, where the difference that existed among fertilizers was found to be insignificant at $(p>0.05)$. On comparing the oxalate content obtained in this work to those of green and variegated cultivars of sorrel (14.7 and $24.4 \mathrm{~g} / 100 \mathrm{~g}$ ) as reported by Tuazon and Savage (2013), the content obtained from Hibiscus sabdariffa studied was recorded lower to those obtained in the later findings. The oxalate tolerable limit is $256 \mathrm{mg} / 100 \mathrm{~g}$, from this investigation the values recorded were at high sight. Ruan et al., (2013) demonstrated that, boiling reduces the level of the anti-nutrients contents in taros plant boiled in water for $40 \mathrm{~min}$, which decreased oxalate contents by at least $47 \%$. The raw sample of $H$. sabdariffa oxalate content can equally be removed in boiling process before been used as diet.

The tannin contents however, found increased with an increase in the fertilizer level, where $M$ fertilizer had the least value, while mineral fertilizer F75 possessed the higher tannin content of $2.756 \%$. Overall, the tannin content obtained was below permissible limit of $76-90 \mathrm{~g} / \mathrm{kg}$ (Alekor, 1995). This indicated that anti-nutrients obtained in this study have no health effect to the dietary value of Hibiscus sabdariffa as far as its vegetative stage is concerned. Though, Hibiscus sabdariffa vegetables will have passed through blanching and boiling process before used as a diet. 
Ilelaboye et al. (2013), reported that, blanching caused a significant reduction of $31.26 \%$ to $49.24 \%$ in the oxalate and further reduction of $39.22 \% \mathrm{~g}$ to $54.42 \%$ was achieved when the blanched vegetables were processed to vegetables' soups. However, there was no significant difference existing among the fertilizers used on the tannin contents $(p>0.05)$.

Table 1; Proximate compositions of Hibiscus sabdariffa (at a vegetative stage) grown under mineral and organic fertilizer levels

\begin{tabular}{|c|c|c|c|c|c|c|}
\hline & & & & & & \\
\hline $\begin{array}{l}\text { Sample } \\
\text { /Parameters }\end{array}$ & $\begin{array}{l}\text { Moisture } \\
\text { content }\end{array}$ & $\begin{array}{l}\text { Ash content } \\
\text { Ash }\end{array}$ & $\begin{array}{l}(\%) \\
\text { Crude } \\
\text { protein }\end{array}$ & $\begin{array}{l}\text { (\%) } \\
\text { Crude fat }\end{array}$ & $\begin{array}{l}(\%) \\
\text { Crude fiber }\end{array}$ & $\begin{array}{l}\text { Carbohydrate } \\
\text { Cor }\end{array}$ \\
\hline$M$ & $\begin{array}{l}6.812 \pm 0.25 \\
3\end{array}$ & $12.411 \pm 0.600$ & $\begin{array}{l}20.910 \pm 2.13 \\
2\end{array}$ & $\begin{array}{l}15.455 \pm 2.428 \\
\text { b }\end{array}$ & $\begin{array}{l}12.047 \pm 0.68 \\
4\end{array}$ & $32.366 \pm 5.555$ \\
\hline F75 & $\begin{array}{l}6.989 \pm 1.05 \\
3\end{array}$ & $12.742 \pm 0.999$ & $\begin{array}{l}15.322 \pm 5.56 \\
8\end{array}$ & $\begin{array}{l}14.402 \pm 4.712 \\
\text { b }\end{array}$ & $11.47 \pm 9.462$ & $\begin{array}{l}42.223 \pm 12.18 \\
4\end{array}$ \\
\hline F100 & $\begin{array}{l}6.504 \pm 0.35 \\
4\end{array}$ & $13.130 \pm 2.564$ & $\begin{array}{l}18.426 \pm 0.70 \\
4\end{array}$ & $\begin{array}{l}30.710 \pm 0.054 \\
\text { a }\end{array}$ & $\begin{array}{l}11.173 \pm 0.05 \\
4\end{array}$ & $41.960 \pm 7.657$ \\
\hline
\end{tabular}

All data were mean \pm standard deviation of triplicate determinations, Mean within a column of parameters followed by unlike letter(s) amongst the treatments $(a, b)$ are significantly different using LSD at $5 \%$ level of significance. $\mathrm{M}=$ manure, $\mathrm{F} 75=75 \mathrm{Kg}$ of fertilizer/ha and $\mathrm{F} 100=100 \mathrm{Kg}$ of fertilizer/ha.

Table 2; Anti-nutrients compositions of Hibiscus sabdariffa (at a vegetative stage) grown under mineral and organic fertilizer levels.

\begin{tabular}{cll}
\hline Sample /Parameters & $\begin{array}{c}(\mathrm{g} / 100 \mathrm{~g}) \\
\text { Oxalate }\end{array}$ & $\begin{array}{c}(\mathrm{g} / 100 \mathrm{~g}) \\
\text { Tannin }\end{array}$ \\
\hline M & $9.978 \pm 2.359$ & $2.685 \pm 0.068$ \\
F75 & $8.455 \pm 3.364$ & $2.756 \pm 0.114$ \\
F100 & $8.190 \pm 0.213$ & $2.736 \pm 0.454$ \\
RDA & $0.256 \mathrm{~g}$ & $7.6-9 \mathrm{~g}$ \\
\hline
\end{tabular}

All data were mean \pm standard deviation of triplicate determinations, Mean within a column of parameters among the treatments were found to be insignificantly different using LSD at $5 \%$ level of significance. $M=$ manure, $F 75=75 \mathrm{Kg}$ of fertilizer/ha and $\mathrm{F} 100=100 \mathrm{Kg}$ of fertilizer/ha.

Table 3; Mineral compositions of Hibiscus sabdariffa (at a vegetative stage) grown under mineral and organic fertilizer levels.

\begin{tabular}{llllll}
\hline $\begin{array}{l}\text { Sample/ } \\
\text { Elements }\end{array}$ & $\mathrm{Mn}$ & $\mathrm{Fe}$ & $\mathrm{Kg})$ & \\
\hline M & $714.810 \pm 0.104$ & $750.311 \pm 2.300$ & $30.689 \pm 0.018$ & $\mathrm{BDL}$ & $18.571 \pm 0.038$ \\
F75 & $586.839 \pm 0.803$ & $922.508 \pm 2.486$ & $30.150 \pm 0.0426$ & $\mathrm{BDL}$ & $10.428 \pm 0.0121$ \\
& & & & & $\mathrm{Cu}$ \\
F100 & $781.717 \pm 1.225$ & $1377.294 \pm 6.543$ & $21.833 \pm 0.102$ & $\mathrm{BDL}$ & $13.222 \pm 0.0387$ \\
WHO & 600.00 & 17.00 & 20.00 & 0.03 & 10.00 \\
\hline
\end{tabular}

All data were mean \pm standard deviation of triplicate determinations, Mean within a column of parameters among the treatments were found to be insignificantly different using LSD at $5 \%$ level of significance.

$\mathrm{M}=$ manure, $\mathrm{F} 75=75 \mathrm{Kg}$ of fertilizer/ha, $\mathrm{F} 100=100 \mathrm{Kg}$ of fertilizer/ha

\section{CONCLUSION}

The findings of this study revealed that, poultry manure has potential over the conventional mineral fertilizers used as there were no significant different existed in nutrients yielding as, ( $\mathrm{Mn}, \mathrm{Fe}, \mathrm{Zn}$ and $\mathrm{Cu}$ ), and also, Ash content, crude protein, crude fiber and carbohydrate. The toxic lead content was therefore obscured, where the moisture level was at remote content which further prevailed the freshness of this vegetable if harness by this fertilizer.More so, the results entailed that, mineral fertilizer $100 \mathrm{~kg} / \mathrm{ha}$ have a good enhancing capacity for the vegetable oil exploitation.

\section{REFERENCES}

Akanbi, W.B., Togun, A.O., J.A. Adediran and E.A.O. Ilupeju (2010). Growth, Dry Matter and Fruit Yields Components of Okra under Organic and Inorganic Sources of Nutrients. Am. Eurasian J. Sustain. Agric., 4(1): 1-13.

Akanya, H.O., S.B. Oyeleke, A.A. Jigam and F.F. Lawal, (1997). Analysis of Sorrel Drink. Nig. J. Biochem., 12: 77-79.

Alekor and Adeogun (1995). Nutrient Components of some Tropical Leafy Vegetables, Food Chem.54(4):375-379 
Bajopas Volume 11 Number 1 June, 2018

Ali, A.H. and M.M. Abdel-Mouty, (2000). Effect of Different Sources of Organic Manure and Sulpher on the Growth and Yield of Okra Plant. Egypt, J. Appl. Sci., 15(11): 282-305.

Allen, S.E., Grimshaw, H.M., Parkison, J.A. and Quarmby, C. (1974).Chemical Analysis of Ecological Material. Black.W. Sci.P:50-317.

AOAC, (2010). Official Methods of Analysis. Association of Official Analytical Chemists, 15th Edn., Washington D.C., USA.

AOAC (1999). Methods of Analysis of Association of official Analytical chemists (16th ed). Washington, D.C.1: 600-792.

AOAC (1995). Official methods of analysis (16th edn) Association of Official Analytical Chemists. Arlington, V. A. USA

Asibey-Berko, E. and Tayie, F.A.K.(1999). Proximate Analysis of some underutilized Ghanaian Vegetables. Ghana J. sci. 39: 91-92.

Dania,

Isikhuemhen, O. (2014). Ethnomedicinal Uses of Mushroom among the Okpameri People in Edo State, Nigeria. A Case Study of Okulosho Enclave. Biological and Environmental Journal for the Tropic (BEST),11(1):135-140.

Dickson, R.A., Annan, K. Fleischer, T.C., Amponsah, K.N. and Oteng, J.A. (2012). Phytochemical Investigations and Nutritive Potential of Eight Selected Plants from Ghana. Journal of Pharmacy and nutrition Sciences, 2(2):2-177.

FAO/WHO(2001). Expert Consultation on Allergenicity of Foods Derived from Biotechnology, January 2001 Evaluation of Allergenicity of Genetically Modified Foods Report of a Joint FAO/WHO Expert Consultation on Allergenicity of Foods Derived from Biotechnology 22 - 25 January 2001 Food and Agriculture Organization of the United Nations (FAO) Rome, Italy.

Fasuyi, A. O. (2006). Nutritional Potentials of Some Tropical Vegetables Meals. Chemical Characterization and Functional Properties. African. J. Biotech. 5(1): 49- 53.

FNB (2001). Food and Nutrition Board, Institute of medicine: Dietary Reference intakes or Vitamin A, Vitamin K, Arsenic, Boron, Molybdenum. Nickel, Silicon, Vanadium and Zinc Washington DC. Standing Committee on Scientific Evaluation of Dietary Reference Intakes. National Academy Press. 2001

Ilelaboye, N.O.A, Amoo, I. A. and Pikuda, O. O. (2013).Effect of Cooking Methods on Mineral and Anti-nutrient Composition of Some Green Leafy Vegetables. Archives of Applied Science Research, 5 (3):254-260

Johnston, L. M., Moe C. L., Moll, D. and Jaykus, L. (2006).The epidemiology of produceAssociated Outbreaks of Food Borne Disease. In: Microbial Hazard Identification in Fresh Fruits and Vegetables (edited by J. James). New Jersey: John Wiley and Sons. Pp. 38-52.

Kadiri, M., Ojewumi, A.W. and Olawale, S. O (2015). Minerals Vitamins and Chlorophyll Contents of
Fruits, Stem and Leaves of Tomato and Garden Egg. Pakistan Journal of Food Sciences, 25(3): 150-154.

Michael, T. M., Mduduzi, M. H., Olusegun, T. O.and Thokozile, E. S. (2010). Effects of Organic Fertilizers on Growth, Yield, Quality and Sensory Evaluation of Red Lettuce (Lactuca sativa L.) 'Veneza Roxa'. Agriculture and Biology Journal of North America(6):13191324.

Mohammed, M. I. and Sharif, N. (2011). Mineral Composition of Some Leafy Vegetables Consumed in Kano, Nigeria. Nig. J. Basic. Appl. Sci. 19(2): 208-211.

NRC, (National Research Council, 1980). Recommended Dietary allowances, 9th Edn. Nat. Acad. Sci. Washington DC., 1980. Pp: 2334.

Ogunlesi, M., Okiei, W., Azeez, L., Obakachi, V., Osunsanmi, M. and Nkenchor, G. (2010).Vitamin C Contents of Tropical Vegetables and Foods Determined by Voltammetric and Titrimetric Methods and Their Relevance to the Medicinal Uses of the Plants.Int. J.of Electrochem. Sc. 5: 105-115.

Onder, U., Ahmet, E. T. and Mursel, O. (2013). Effect of Glycerol supplemented Diet Fed Different Ages on Growth Performance and Some Blood Parameters in Japanese Quails Journal of International Scientific Publications. Agriculture \& Food, 1(1): 1314-8591

Parr, J.F. and Hornick, S.B. (1990). Recent Development in Alternative Agriculture in the United State. In Pro.of In thl Conf. on Kyussei Nature Forming. October 17-29, 1989, Khankean Univ Thailand.

Ren, T., Wang, J., Chen, Q., Zhang, F. and Lu, S.(2014). The Effects of Manure and Nitrogen Fertilizer Applications on Soil Organic Carbon and Nitrogen in a High-Input Cropping System. PLoS ONE 9(5): e97732. doi:10.1371/journal.pone.0097732

Ruan, Q.Y., Zhenga, X.Q., Chena, B.L., Xiao, Y. P., David, X.X., Leung, W.M. and Liu, E.E.(2013). Determination of Total Oxalate Contents of a Great Variety of Foods Commonly Available in Southern China Using an Oxalate Oxidase Prepared from Wheat Bran. Journal of Food Composition and Analysis, 32:6-11.

Schiffers, R. R. (2000). Economic and Social Importance of Indigenous African Vegetables: African Indigenous Vegetables, An overview of the Cultivated Species. Natural Resource Institute/ACP-EU Technical Centre for Agriculture and Rural Cooperation. Chatham, U.K. Pp.1-124.

Tindal, H.D., (1986). Vegetable in the Tropics Macmillan Edn. Ltd. Hampshire, Pp. 267-268.

Tuazon, J.N. and Savage, G.(2013). Investigation of oxalate levels in sorrel plant part-based products. Journal of biomedical and Science, $4(8): 838-843$ 